\title{
PRESCHOOL PEDAGOGY IN THE SYSTEM OF CONTEMPORARY UNIVERSITY EDUCATION OF FUTURE KINDERGARTEN TEACHERS
}

\author{
Emina Kopas-Vukasinovic, PhD, \\ Associate Professor of preschool pedagogy, \\ Senior Research Associate \\ The Faculty of Pedagogy, Jagodina (Serbia) \\ e-mail: ekopas@rcub.bg.ac.rs
}

\begin{abstract}
A b s tract
The paper starts with the belief that the contents of preschool pedagogy are essential for the preparation of future kindergarten teachers for work in preschool institutions. Within the system of university education of students, these contents have both the quality of general and of specific knowledge necessary for the execution of preschool work. The paper further presents the theoretical model of an organised system of activities that are realised with students in preschool pedagogy classes. This system has various functions, from the acquisition of theoretical knowledge to the possibilities of their practice. The level of students' interest in organised educational activities and their achievements in knowledge examination are the elements for evaluation of this model. These elements are presented here as the results of analysis.
\end{abstract}

Key words: preschool pedagogy, university education of kindergarten teachers, system of activities, interests of students, achievements of students.

\section{Introduction}

The system of university education of future kindergarten teachers involves the implementation of the curriculum to prepare them for quality work with preschool children. It is essential that students acquire knowledge on a wide range of individual characteristics and the specifics of child development from birth to school age, on possibilities to organize activities in function of their quality development and learning before entering school. Preschool pedagogy is one of the essential disciplines of pedagogy in the curriculum for students - future kindergarten teachers in preschool institutions. The contents of this course are complementary to other pedagogical and related courses (Introduction to Pedagogy, Family Pedagogy, Didactics, Developmental Psychology, etc.). At the Faculty of Pedagogy in 
Jagodina, preschool pedagogy is studied during the third and fourth semester. The contents of this course are essential for further study and understanding of the content covered by specialized professional courses (Methods of upbringing and educational work, Methods of speech development, Methods of learning about environment, Methods of development of fundamental mathematical concepts, ...). It is therefore important to develop a system of activities for students in preschool pedagogy classes, as a function of mastering the content of this course. The quality of the acquired knowledge in their university education represents the basis necessary for the study of new instructional contents. This system of activities involves two aspects of implementation, in relation to the time of implementation and in relation to the type of activity with students. Model of system of activities, which will be presented in this paper, is the result of years of teacher's work with students in the realization of the contents of preschool pedagogy. The good achievement of students in classes and their interest in the activities confirm the justification for the existence of this model.

\section{Preschool pedagogy instructional contents and system of activities for students}

Which instructional contents are studied in preschool pedagogy and how do they relate to other courses in the university curriculum for kindergarten teachers in preschool institutions? We will try to answer this question with a schematic presentation of instructional themes in preschool pedagogy and their connection with the contents of other courses. The fact is that the comprehensiveness of instructional material makes Preschool Pedagogy an essential course in preparing students for work with children in preschool institutions. The contents of this course are important for the acquisition of new knowledge in the courses that will later be taught and for training students to apply this knowledge in practice.

Scheme 1 clearly represents a three-stage preschool pedagogy connection with other courses (Undergraduate Studies ..., 2008). The first, most fundamental level is its connection with philosophy, psychology and sociology, in terms of connecting the idea of world and life, then the idea of human development and education, and social conditioning of education. The following step in concretization of the content represents the connection of preschool pedagogy with other pedagogical disciplines (Introduction to pedagogy, Family pedagogy, Methodology of pedagogical research). Students acquire knowledge about the development of ideas and specifics of education of children from birth to school age, the possibilities of unified action of families and preschool institutions in the upbringing of children. They are prepared for research and improvement of pedagogical practice, learning and development of preschool children. The third level of concretization of the content of preschool pedagogy involves its association with specialized professional courses, primarily with individual methods, in order to prepare students for a quality upbringing and educational work with children in preschool institutions. 
Such connections of the preschool pedagogy instructional contents can justify its status of an essential pedagogical discipline in the curriculum for the university education of future kindergarten teachers in preschool institutions.

Scheme 1: Instructional themes for the course of Preschool pedagogy and its connection with other courses and pedagogical disciplines in university education of kindergarten teachers in preschool institutions

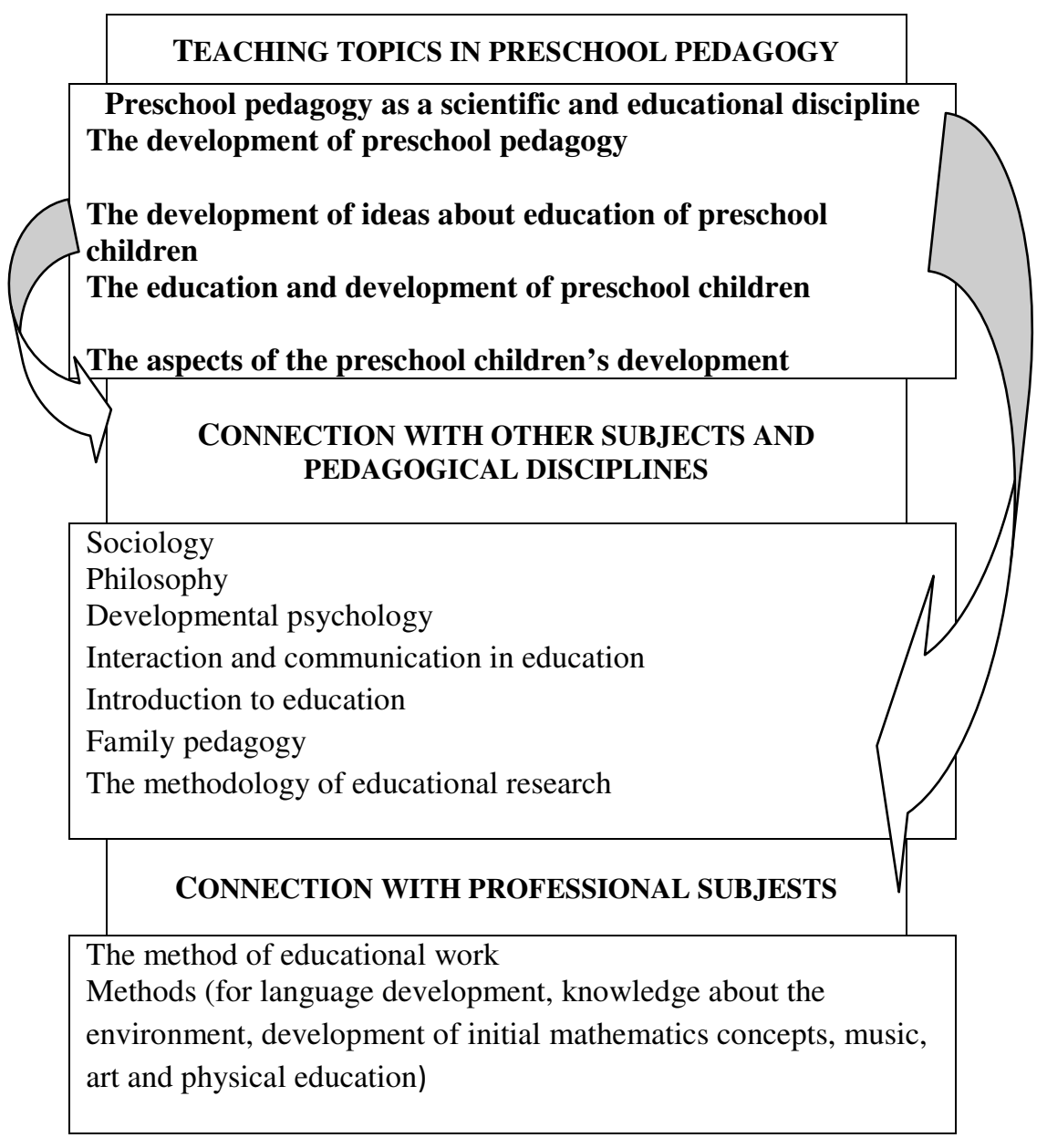

The next step in this paper involves determining the system of activities for students, allowing them a complete understanding and adoption of instructional materials, followed by the transfer of the knowledge acquired in other courses and during pedagogical practice. What is the system of student activities that is implemented through preschool pedagogy instructional contents? What are its functions in preparing students for future work as kindergarten teachers in preschool institutions? Table 1 gives us the answers to these and other questions. It 
systematizes the pre-exam activities of students during two semesters, in which they studied the content of preschool pedagogy. Systematization was determined with respect to the planned instructional contents, the time for their implementation and application of gradual complexity of students' activities. Please note that these activities do not involve a formal review of students' knowledge (through knowledge tests or colloquium tests). It is about mastering the instructional contents through theoretical and practical activities for students, which derive from each other. Some of these activities are mandatory for all students (Action research in the first semester), while other activities are at students' choice (e.g., display and analysis of reference). In this way they conduct self-check of acquired knowledge from preschool pedagogy, expanding it and connecting with knowledge from other (above mentioned) courses. They then apply them in working with preschool children during organized pedagogical practice. In such a comprehensive way, the students prepare themselves during the two semesters for the exam in preschool pedagogy.

Table 1: System of students' activities in preschool pedagogy classes

\begin{tabular}{|c|c|c|}
\hline Semester & Instructional contents & $\begin{array}{c}\text { Students' activities } \\
(\mathrm{MA}=\text { mandatory activity; } \\
\text { OA=optional activity) }\end{array}$ \\
\hline \multirow{4}{*}{ III } & $\begin{array}{l}\text { Basics of preschool } \\
\text { pedagogy }\end{array}$ & $\begin{array}{l}\text { Connections and relations between the } \\
\text { concepts and reflections of their } \\
\text { definitions in practice - defining } \\
\text { concepts and analysis of the example of } \\
\text { good practice (OA) }\end{array}$ \\
\hline & $\begin{array}{l}\text { Education and } \\
\text { development factors }\end{array}$ & $\begin{array}{l}\text { Environmental impact on a child of } \\
\text { preschool age - preschool child } \\
\text { behaviour observation and analysis of } \\
\text { examples (OA) }\end{array}$ \\
\hline & $\begin{array}{l}\text { Patterns and } \\
\text { characteristics of a } \\
\text { preschool child } \\
\text { development }\end{array}$ & $\begin{array}{l}\text { Age characteristics and specificity of } \\
\text { development of preschool children, the } \\
\text { developmental aspects - analysis of the } \\
\text { developmental map (OA) }\end{array}$ \\
\hline & $\begin{array}{l}\text { Action research in a } \\
\text { preschool institution }\end{array}$ & $\begin{array}{l}\text { Preparation of action research projects } \\
\text { (MA) }\end{array}$ \\
\hline IV & $\begin{array}{l}\text { Aspects for development } \\
\text { of preschool children }\end{array}$ & $\begin{array}{l}\text { Realization of action research projects } \\
\text { for students (during the pedagogical } \\
\text { practice, in the third and fourth } \\
\text { semester) and preparation of the Power } \\
\text { Point Presentation (MA) }\end{array}$ \\
\hline
\end{tabular}

Systematic activities of students are aimed at quality organization of preschool pedagogy classes and the gradual introduction of the complexity in teaching. Such planned activities allow students to systematize their knowledge. 
Such a created system of knowledge is the outcome of the process of students' learning in classes, through their own actions and working together with teachers, which is a presumption for the realization of the didactic principles of the activities of the learner in the instructional process (Antonijević, 2006). Through integration and systematization of the instructional contents, the teacher creates the conditions in which students will understand them better while studying, be interested in their integration with other features of preschool pedagogy and related courses, and finally be trained to apply them in practice.

Gradually connecting content and complexity of activities creates conditions in which the students realize the importance of studying the instructional contents, and become interested in their implementation and verification in practice to obtain a quality preparation for their future jobs. This includes highly qualified and wellprepared university teachers, who are expected to implement the teaching, monitor its effects and improve it. The quality of teaching can be viewed from two angles: through the implementation of classes and the achievement of pupils (students), because the instructional process is determined by planning, organization and evaluation of teaching (Avramović and Vujačić, 2010). In the system of modern university education both the teachers (those who teach) and the students (those who learn) are responsible for the quality of classes. Their activities complement each other and determine the direction of further action of the teacher and every student. It must be aligned with the goals that each one of them has, in relation to the final effects of organized instructional activities. In the system of university education of future kindergarten teachers, these effects include the applicability of acquired knowledge in activities with preschool children. A teacher, who is qualified to operate effectively in the instructional process and encourages students to carry out an activity, must have well developed communication abilities and skills. He uses interactive teaching methods, creates the conditions for the emergence of situational interest of students and encourages their autonomy in selecting activities (Kopas-Vukašinović and Andjelković, 2006; Kopas-Vukašinović, 2009; Pavlović, 2006). Today, the roles of teachers and students are significantly changing in relation to the traditional system of university education. Interaction and communication in the instructional process create conditions in which students acquire knowledge that is not given in its final form. It is gradually expanded, under the influence of new experiences, and then connected and deepened (as a system of concentric circles), which is an important skill for future kindergarten teachers for work with children of preschool age (Bonkovski, 2009; Kopas-Vukašinović, 2005; Lepičnik-Vodopivec, 2009; Petrović-Sočo, 2010).

Activities for students in preschool pedagogy classes help students to prepare for colloquium tests, in the third and fourth semester, and then for the final, oral examination. From defining the basic concepts, through observation, and action research, students acquire theoretical knowledge and enable the recognition and application of knowledge in working with preschool children. Organized pedagogical practice for students gives them the opportunity to check how well they have mastered the instructional contents, whether and how they can be applied in practice. 
How much are the students interested in such an organized system of activities and what are their views on the applicability of acquired knowledge in practice? We have received the answers to these questions from students themselves, by examining their views.

\section{Survey}

The survey was conducted among the second year students at the Faculty of Pedagogy in Jagodina, during the academic year 2010/2011. For the purposes of this study, data were collected during the fall semester and are part of a larger study on the quality of modern teaching. Fifty-six students were tested.

Table 2: The view of students on the quality of activities in preschool pedagogy classes

\begin{tabular}{|c|c|c|c|c|c|c|c|c|c|c|}
\hline \multirow{3}{*}{ CLAIM } & \multicolumn{10}{|c|}{ The degree of agreement with the statement } \\
\hline & \multicolumn{2}{|c|}{$\begin{array}{l}\text { I strongly } \\
\text { agree } \\
\text { (4) }\end{array}$} & \multicolumn{2}{|c|}{$\begin{array}{l}\text { I mostly } \\
\text { agree } \\
\text { (3) }\end{array}$} & \multicolumn{2}{|c|}{$\begin{array}{l}\text { I don't } \\
\text { know } \\
(2)\end{array}$} & \multicolumn{2}{|c|}{$\begin{array}{l}\text { I mostly } \\
\text { disagree } \\
\text { (1) }\end{array}$} & \multicolumn{2}{|c|}{$\begin{array}{c}\text { I strongly } \\
\text { disagree } \\
\text { (0) }\end{array}$} \\
\hline & Nr. & $\%$ & Nr. & $\%$ & Nr. & $\%$ & $\mathrm{Nr}$. & $\%$ & Nr. & $\%$ \\
\hline $\begin{array}{l}\text { Activities that students } \\
\text { implement in } \\
\text { preschool pedagogy } \\
\text { classes contribute to } \\
\text { the increase of their } \\
\text { interest in this course. }\end{array}$ & 14 & 25.0 & 35 & 62.5 & 7 & 12.5 & - & - & - & - \\
\hline $\begin{array}{l}\text { Acquired knowledge } \\
\text { in preschool pedagogy } \\
\text { classes is applicable in } \\
\text { activities with children } \\
\text { during organized } \\
\text { pedagogical practice } \\
\text { for students. }\end{array}$ & 19 & 33.9 & 33 & 58.9 & 4 & 7.1 & - & - & - & - \\
\hline
\end{tabular}

The goal was to determine how many students were interested in planned activities in preschool pedagogy classes, which were realized according to the plan, during the third and fourth semester.

Two tasks of the survey were established:

1. To determine whether the planned activities contribute to the increase of the students' interest in the contents of preschool pedagogy;

2. To determine the views of students on the applicability of acquired knowledge in practice.

Students were asked to express their views on the scale of the degree of their agreement, by circling one of the numerical values for each view (Table 2). 


\section{Results and discussion}

The views of students confirmed the expressed theoretical statement that by integration and systematization of educational contents the teacher creates the conditions in which students will be interested in their study. Most students believe that activities implemented with the professor in preschool pedagogy classes contribute to the increase of their interest in this course $(87.50 \%)$. This was confirmed by selected alternatives "I strongly agree" and "I mostly agree". Other students $(12.50 \%)$ did not have a clear view on whether organized activities encourage their interests and opted for the alternative "I don't know." Students' views are an important indicator of the quality of the system of activities, implemented in preschool pedagogy classes. During the selection and preparation of activities for students, we were guided by the requirements of preschool pedagogy as a scientific and educational discipline, possibilities and needs of students, future kindergarten teachers in preschool institutions. Their interests have been foreseen as the effects of a formed system of activities.

Next we wanted to determine the views of students on how the knowledge acquired in preschool pedagogy classes can be applied in working with children of preschool age. Students have expressed their degree of agreement with the above statement after their stay at the preschool institution, organized in pedagogical practice. Only $7.14 \%$ of the students in this case opted for the alternative "I don't know", and the remaining $92.86 \%$ strongly $(33.93 \%)$ or mostly $(58.93 \%)$ agreed with the statement that their knowledge of preschool pedagogy is applicable. These views of students once again confirmed the effectiveness of an organized system in preschool pedagogy classes. In the theoretical part of this paper it was stressed out that the interaction and communication in the instructional process included the acquisition of knowledge that cannot be given in its final form, but is in constant expansion and integration, which is an important skill for future kindergarten teachers for work with children. This conclusion is confirmed by the views of students that the acquired knowledge is applicable.

It should be noted that in the system of activities in preschool pedagogy classes, a sustained consulting work of teachers with students is organized. During the preparation and implementation of activities, students were given answers to questions and instructions for working with children. In small groups, with the help of their professors, they resolved dilemmas and thus prepared for the implementation of the tasks they were given. It is believed that such cooperation has helped students to successfully perform the activity, after which they expressed positive views about their interest in instructional contents and applicability of the acquired knowledge. 


\section{Conclusion}

In the system of university education of future kindergarten teachers, organized activities for students determine their level of interest for instructional contents. Preschool pedagogy, as a scientific discipline, enables students to acquire a high-quality and applicable knowledge. The established system of activities directs their interests and encourages them to adopt new knowledge and to apply it and test in practice. In this system the sustained cooperation of students and teachers is achieved in function of understanding and quality performing of the tasks.

In order to further improve education, the existing system of activities will be supplemented with new tasks for students (and the professor) in order to further concretize the instructional contents and their connections. Along with the development of this system, a system of monitoring student achievements in preschool pedagogy classes will be developed. How much has the system of activities contributed to improving students' success at the end of the year? Do they see the significance of this system? How do students evaluate the involvement of teachers in the system of instructional activities? We will look for the answers to these questions in the research that will be implemented in the spring semester. These are some of the questions that will stimulate other researchers to further address the problem of quality of university teaching.

\section{Bibliography}

Antonijević, R. (2006): Povezivanje i sistematizacija znanja u nastavi, u Krnjajić, S. (prir.): Pretpostavke uspešne nastave (89-110). Beograd: Institut za pedagoška istraživanja.

Avramović, Zoran i Milja Vujačić (2010): Nastavnik između teorije i nastavne prakse. Beograd: Institut za pedagoška istraživanja.

Bonkovski, R. (2009): Ciljevi i zadaci nastave studijskog predmeta Opisna gramatika srpskog jezika, na poljskim univerzitetima, Obrazovanje $i$ usavršavanje nastavnika - ciljevi $i$ zadaci vaspitno-obrazovnog rada (361-368). Užice: Učiteljski fakultet.

Kopas-Vukašinović,E. (2005):Višefrontalna evaluacija rezultata studenata, Zbornik: Savremene koncepcije, shvatanja i inovativni postupci u vaspitno-obrazovnom i nastavnom radu $i$ mogućnosti primene u savremenoj školi (643-649), Novi Sad, Filozofski fakultet.

Kopas-Vukašinović, E. i S. Anđelković (2006): Kvalitet rada univerzitetskih profesora, Pedagogija, LXI, 3 (349-357).

Kopas-Vukašinović Emina (2009): The Professional Internship of Future Teachers: Requests and Dilemmas, in Matti Meri (Ed.), Proceedings of the International Conference Promoting Teacher Education from Intake System to Teaching Practice (85-94). Jagodina: Faculty of Education, University of Kragujevac (Srbija).

Lepičnik-Vodopivec, J. (2009): Reasons why Future Educators of Preschool Children Chose the Pedagogic Profession, in: Dani Mate Demarina - Škola po mjeri (63-174). Pula: Sveučilište Jurja Dobrile u Puli, Odjel za obrazovanje učitelja i odgojitelja.

Osnovne akademske studije za sticanje stručnog naziva vaspitač u predškolskim ustanovama (Knjiga predmeta) (2008). Jagodina: Pedagoški fakultet u Jagodini. 
Pavlović, B.(2006): Činioci i izazovi uspešnog obrazovanja za građansko društvo, Zbornik Instituta za pedagoška istraživanja, Vol. 38, Br.1 (205-224). Beograd: Institut za pedagoška istraživanja.

Petrović-Sočo, B. (2010): Prema pedagogiji slušanja i razumijevanja, 11 dani Mate Demarina - Očekivanja, postignuća i perspektive u teoriji i praksi ranog i primarnog odgoja $i$ obrazovanja (333-344). Zagreb: Učiteljski fakultet Sveučilišta u Zagrebu.

Note: This article is the result of the project „Improving the quality and accessibility of education in modernization processes in Serbia" No 47008 (2011-2014), financially supported by the Ministry of Science and Techological Development of the Republic of Serbia, and of the project „From encouraging initiative, cooperation and creativity in education to new roles and identities in society" No 179034 (2011-2014), financially supported by the Ministry of Science and Techological Development of the Republic of Serbia.

Metodički obzori 7(2012)1

Preliminary announcement UDK: 378.637 .32

Received: 10. 1.2011.

\title{
PREDŠKOLSKA PEDAGOGIJA U SISTEMU SAVREMENOG UNIVERZITETSKOG OBRAZOVANJA BUDUĆIH VASPITAČA
}

\author{
Dr Emina Kopas-Vukašinović, vanredni profesor \\ Pedagoški fakultet, Jagodina, Srbija \\ e-mail: ekopas@ rcub.bg.ac.rs
}

\begin{abstract}
Apstrakt
U radu se pošlo od stanovišta da su sadržaji predškolske pedagogije bazičnog karaktera za pripremu budućih vaspitača za rad u predškolskim ustanovama. U sistemu univerzitetskog obrazovanja studenata, ovi sadržaji istovremeno imaju karakter opštih i specifičnih znanja, neophodnih za ostvarivanje kvalitetnog pedagoškog rada. Predstavljen je teorijski model organizovanog sistema aktivnosti, koje se realizuju sa studentima kroz nastavne sadržaje predškolske pedagogije. Ovaj sistem ima višestruke funkcije, od sticanja teorijskih znanja do mogućnosti njihove primene. Nivo zainteresovanosti studenata za organizovane nastavne aktivnosti i njihova postignuća na testovima znanja, predstavljaju elemente evaluacije ovog modela, koji su u radu prikazani kao rezultati istraživanja.
\end{abstract}

Ključne reči: predškolska pedagogija, univerzitetsko obrazovanje vaspitača, sistem aktivnosti, interesovanja studenata, postignuća studenata. 